\title{
Does Prophylactic CPAP Have Any Role in Thoracic Surgery?
}

Despite significant improvement in perioperative management, the mortality and morbidity after thoracic surgery still remain high. ${ }^{1,2}$ In a very large database that included more than 3,000 patients receiving major pulmonary resection for cancer disease, the mortality rates were $4 \%$ and $11.5 \%$ for lobectomy and pneumonectomy, respectively. ${ }^{3}$ The main reported causes of death included acute respiratory failure, myocardial infarction, and hemorrhage. ${ }^{3,4}$ The independent risk factors for mortality were the transfusion of more than 4 units of red blood cells, age, a low serum albumin level, coagulopathy, and dyspnea.

Regarding the postoperative pulmonary complications, Stephan et al found that prolonged air leak and bronchopleural fistula were the most frequent, followed by bacterial pneumonia and acute respiratory failure. ${ }^{5}$ An operation time longer than 80 minutes, the need of mechanical ventilation, and an American Society of Anesthesiology score higher than 3 significantly increased the risk for postoperative pulmonary complications. ${ }^{5}$ Conflicting results regarding the role of pulmonary function tests in predicting pulmonary complications have been reported. ${ }^{6-8}$ In a retrospective analysis of patients with pulmonary resection, the frequency of acute lung injury and ARDS was $3.9 \%$, and was related to the extension of lung resection. ${ }^{2,9}$ Acute lung injury/ARDS was present in $2.8 \%$ of patients $<60$ years old, and $4.9 \%$ of patients $>60$ years of age. The mortality rate in patients with ARDS was higher in pneumonectomy, compared to lobectomy ( $33 \%$ vs $25 \%$ ). ${ }^{2}$

The main pulmonary modifications induced by anesthesia and surgery are related to the reduction in lung volumes and in muscle strength. The reduction in lung volumes is related to the extension of the resections; in particular, the $\mathrm{FEV}_{1}$ is usually reduced between $0.45-0.84 \mathrm{~L}$, and the FVC between 0.94 and $1.50 \mathrm{~L} .{ }^{10}$ The alveolar collapse is localized in the more dependent lung regions and may also persist for days after the surgery. ${ }^{11,12}$ Consequently, the simultaneous presence of lung atelectasis, sputum retention, and muscle dysfunction can increase the risk of acute respiratory failure. Among the different postoperative interventions to prevent/ minimize lung atelectasis, such as an adequate pain management and chest physiotherapy, CPAP has been advocated. ${ }^{13}$ CPAP, in intubated or not intubated patients, by applying a continuous positive pressure during the whole respiratory cycle,${ }^{14}$ should in theory increase the transpulmonary pressure, restore lung aeration, improve functional residual capacity, increase oxygenation, and reduce intrinsic PEEP. ${ }^{15}$ In con- trast to the good theoretical basis of the application of CPAP in postoperative lung surgery, data to support it are still lacking. ${ }^{16}$

See the Original Study on Page 363

In this issue of Respiratory CARE, Nery et al evaluate the prophylactic use of CPAP in thoracic postoperative patients, in terms of pulmonary function and air leakage through the chest tube. ${ }^{17}$ Patients were excluded if they required mechanical ventilation or presented hemodynamic instability or severe pain. Thirty patients were allocated to receive, after elective lung resection, 2 daily sessions of 30 min of CPAP delivered via a face mask for 7 days, compared to only breathing exercises. The level of CPAP applied was $10 \mathrm{~cm} \mathrm{H}_{2} \mathrm{O}$. The use of CPAP significantly increased the FVC and limited the decrease in the performance of the 6-min walk test at day 7, compared to day 1 . Although this was not a randomized study, without data on stay or outcome, the results of this study are welcome, due the paucity of the data available on this topic. In a previous study, Perrin et al evaluated bi-level ventilation, at inspiratory and expiratory pressures of 8 and $4 \mathrm{~cm} \mathrm{H}_{2} \mathrm{O}$, in postoperative lobectomy patients presenting a preoperative $\mathrm{FEV}_{1}<70 \%$ of the predicted value. ${ }^{18}$ The bi-level ventilation was applied for 3 days. The bi-level ventilation significantly improved the gas exchange and the spirometric data, compared to chest physiotherapy.

Along the same line, Aguilo et al investigated the shortterm effects of bi-level ventilation in patients after elective lung resection. ${ }^{19}$ The bi-level ventilation was delivered using a nasal mask with mechanical ventilation with an inspiratory and expiratory pressure similar to those uses in the study of Perrin et al. ${ }^{18}$ After 60 minutes the bi-level ventilation increased the arterial oxygenation without affecting the carbon dioxide or dead space.

A possible side effect of the use of any positive mechanical ventilation, especially after thoracic surgery, is barotrauma, with well known complications such as pneumothorax and air leak..$^{20,21}$ The presence of a persistent air leak has been found to lead to increase in pulmonary morbidity and stay. ${ }^{22,23}$ Varela et al reported, in a case series of patients after pulmonary lobectomy, a $9.7 \%$ prevalence of air leak, associated with a higher nosocomial respiratory infections and pulmonary atelectasis. ${ }^{24}$ 


\section{Does Prophylactic CPAP Have Any Role in Thoracic Surgery?}

The risk of barotrauma is directly related to the transpulmonary pressure. CPAP, and, moreover, bi-level ventilation, by applying a positive pressure, will increase the transpulmonary pressure. However, the transpulmonary pressure will depend on the level of airway pressure, on the mechanical characteristics of the lung and chest wall, ${ }^{25}$ and on the level of muscle activity. ${ }^{26}$ Thus it is not possible to predict the "real" risk of barotrauma by the simple airway pressure set on the ventilator. However, in the previous study, ${ }^{19}$ as well in the present, noninvasive ventilation did not cause any increase in the air leak, compared to chest physiotherapy. ${ }^{17}$

Based on the available findings, the prophylactic use of CPAP or bi-level ventilation at a low level of airway pressure is safe and could slightly ameliorate, at least in the short-term period, the lung function after thoracic surgery.

Davide Chiumello MD Silvia Coppola MD

Dipartimento di Anestesia Rianimazione (Intensiva e Subintensiva) e Terapia del Dolore

Fondazione Istituto di Ricovero e

Cura a Carattere Scientifico

Ca' Granda-Ospedale Maggiore Policlinico Milano, Italy

\section{REFERENCES}

1. Ginsberg RJ, Hill LD, Eagan RT, Thomas P, Mountain CF, Deslauriers $\mathrm{J}$, et al. Modern thirty-day operative mortality for surgical resections in lung cancer. J Thorac Cardiovasc Surg 1983;86(5):654658.

2. Sen S, Sen S, Sentürk E, Kuman NK. Postresectional lung injury in thoracic surgery pre and intraoperative risk factors: a retrospective clinical study of a hundred forty-three cases. J Cardiothorac Surg 2010;5:62.

3. Harpole DH Jr, DeCamp MM Jr, Daley J, Hur K, Oprian CA, Henderson WG, Khuri SF. Prognostic models of thirty-day mortality and morbidity after major pulmonary resection. $\mathrm{J}$ Thorac Cardiovasc Surg 1999;117(5):969-979.

4. Keagy BA, Lores ME, Starek PJ, Murray GF, Lucas CL, Wilcox BR. Elective pulmonary lobectomy: factors associated with morbidity and operative mortality. Ann Thorac Surg 1985;40(4):349-352.

5. Stephan F, Boucheseiche S, Hollande J, Flahault A, Cheffi A, Bazelly B, Bonnet F. Pulmonary complications following lung resection: a comprehensive analysis of incidence and possible risk factors. Chest 2000;118(5):1263-1270

The authors have disclosed no conflicts of interest.

Correspondence: Davide Chiumello MD, Dipartimento di Anestesia, Rianimazione (Intensiva e Subintensiva) e Terapia del Dolore, Fondazione Istituto di Ricovero e Cura a Carattere Scientifico, Ca' Granda - Ospedale Maggiore Policlinico, via Francesco Sforza 35, 20122 Milano, Italy. E-mail: chiumello@libero.it.

DOI: $10.4187 /$ respcare. 01754
6. Harpole DH, Liptay MJ, DeCamp MM Jr, Mentzer SJ, Swanson SJ, Sugarbaker DJ. Prospective analysis of pneumonectomy: risk factors for major morbidity and cardiac dysrhythmias. Ann Thorac Surg 1996;61(3):977-982

7. Abolhoda A, Liu D, Brooks A, Burt M. Prolonged air leak following radical upper lobectomy: an analysis of incidence and possible risk factors. Chest 1998;113(6):1507-1510.

8. Gerson MC, Hurst JM, Hertzberg VS, Baughman R, Rouan GW, Ellis K. Prediction of cardiac and pulmonary complications related to elective abdominal and noncardiac thoracic surgery in geriatric patients. Am J Med 1990;88(2):101-107.

9. Kutlu CA, Williams EA, Evans TW, Pastorino U, Goldstraw P. Acute lung injury and acute respiratory distress syndrome after pulmonary resection. Ann Thorac Surg 2000;69(2):376-380.

10. Win T, Groves AM, Ritchie AJ, Wells FC, Cafferty F, Laroche CM. The effect of lung resection on pulmonary function and exercise capacity in lung cancer patients. Respir Care 2007;52(6):720-726.

11. Magnusson L, Spahn DR. New concepts of atelectasis during general anaesthesia. Br J Anaesth 2003;91(1):61-72.

12. Eichenberger A, Proietti S, Wicky S, Frascarolo P, Suter M, Spahn DR, Magnusson L. Morbid obesity and postoperative pulmonary atelectasis: an underestimated problem. Anesth Analg 2002;95(6): 1788-1792.

13. Brooks-Brunn JA. Postoperative atelectasis and pneumonia. Heart Lung 1995;24(2):94-115.

14. Braschi A, Iotti G, Locatelli A, Bellinzona G. Functional evaluation of a CPAP circuit with a high compliance reservoir bag. Intensive Care Med 1985;11(2):85-89.

15. Ferreyra GP, Baussano I, Squadrone V, Richiardi L, Marchiaro G, Del Sorbo $\mathrm{L}$ et al. Continuous positive airway pressure for treatment of respiratory complications after abdominal surgery: a systematic review and meta-analysis. Ann Surg 2008;247(4):617-626.

16. Chiumello D, Chevallard G, Gregoretti C. Non-invasive ventilation in postoperative patients: a systematic review. Intensive Care Med 2011;37(6):918-929.

17. Nery FP, Lopes AJ, Domingos DN, Cunha RF, Peixoto MG, Higa C, et al. CPAP increases 6-minute walk distance after lung resection surgery. Respir Care 2011;57(3):363-369.

18. Perrin C, Jullien V, Venissac N, Berthier F, Padovani B, Guillot F, et al. Prophylactic use of noninvasive ventilation in patients undergoing lung resectional surgery. Respir Med 2007;101(7):1572-1578.

19. Aguilo R, Togores B, Pons S, Rubi M, Barbe F, Agusti AG. Noninvasive ventilatory support after lung resectional surgery. Chest 1997;112(1):117-121.

20. Della Rocca G, Coccia C. Ventilatory management of one-lung ventilation. Minerva Anestesiol 2011;77(5):534-536.

21. Villar J, Blanco J, Zhang H, Slutsky AS. Ventilator-induced lung injury and sepsis: two sides of the same coin? Minerva Anestesiol 2011;77(6):647-653.

22. Rice TW, Okereke IC, Blackstone EH. Persistent air-leak following pulmonary resection. Chest Surg Clin North Am 2002;12(3):529-539.

23. Bardell T, Petsikas D. What keeps postpulmonary resection patients in hospital? Can Respir J 2003;10(2):86-89.

24. Varela G, Jimenez MF, Novoa N, Aranda JL. Estimating hospital costs attributable to prolonged air leak in pulmonary lobectomy. Eur J Cardiothorac Surg 2005;27(2):329-333.

25. Chiumello D, Carlesso E, Cadringher P, Caironi P, Valenza F, Polli $\mathrm{F}$, et al. Lung stress and strain during mechanical ventilation for acute respiratory distress syndrome. Am J Respir Crit Care Med 2008;178(4):346-355.

26. Kindgen-Milles D, Buhl R, Loer SA, Muller E. Nasal CPAP therapy: effects of different CPAP levels on pressure transmission into the trachea and pulmonary oxygen transfer. Acta Anaesthesiol Scand 2002;46(7):860-865 